\title{
Effects of sericea lespedeza root exudates on some perennial grasses
}

\author{
K.L. KALBURTJI AND J.A. MOSJIDIS
}

Authors are lecturer, Lab of Ecology, Faculty of Agriculture, Aristotelian University of Thessaloniki, 54006 Thessaloniki, Greece; and associate professor, Dept. of Agronomy and Soils and Ala. Agr. Exp. Sta., Auburn University, Auburn 36849-5412.

\begin{abstract}
Root exudates are substances released into the surrounding medium by healthy and intact plant roots. Research on root exudates has shown that root exudates can reduce seed germination and plant growth. There is no information on the effect of sericea lespedeza [Lespedeza curteata (Dum. de Cours) G. Don.] root exudates on other plants. In a series of greenhouse experiments we studied (1) if serices root exudates affect seed germination and seedling growth of the perennial grasses tall fescue (Festuca arundinacea Schreb.), bermudagrass [Cynodon dactylon (L.) Pers.], and bahiagrass (Paspalum notatum Flugge); and (2) if any such responses were cultivar dependent. The effects of the root exudates were measured in 2 experiments. In the first one, coarse perlite was used as medium to measure seed germination and radicle and

Jiansheng Qiu and Paul Crow assisted with data analysis and greenhouse experiments. Journal Publication 3-912899P.

Manuscript accepted 22 Nov. 1992.
\end{abstract}

coleoptile growth. In the second experiment, soil was used as a medium to measure emergence and biomass. Root exudates from sericea lespedeza had no effect on germination and emergence of tall fescue and bahiagrass but reduced their radicle and coleoptile length and biomass. Germination, radicle, and coleoptile length, and emergence of bermudagrass decreased when exposed to the root exudates; however, biomass was not affected. Cultivars of the grass species differed in their response to the root exudates of sericea lespedeza. Thus, establishment of tall fescue in mixture with sericea lespedeza is not likely to be affected; however, its growth is likely to be decreased. Therefore, tall fescue contribution to total yield will be reduced. Conversely, establishment of bermudagrass is likely to be affected, but once established, its growth is expected to be similar to its grown alone.

Key Words: allelopathy, Lespedeza cuneata, tall fescue, Festuca arundinacea, bermudagrass, Cynodon dactylon, bahiagrass, Paspalum notatum 
Root exudates are substances released into the surrounding medium by healthy and intact plant roots (Rovira 1969). They have been implicated in interactions among plants and soil microorganisms (Rovira 1969, D’ Arcy Lameta and Jay 1987, Richardson et al. 1988) and plant-plant interactions (Rovira 1969). Research on root exudates has shown that they can reduce seed germination and plant growth (Pope et al. 1985a, b; Kalburtzi et al. 1989). Hence, root exudates may be of importance in intercropping and crop rotation.

Sericea lespedeza [Lespedeza cuneata (Dum. de Cours) G. Don.] is a perennial legume well adapted to infertile soils which has been grown in association with grasses to extend the production season of pastures (Hoveland and Donnelly 1985). Sericea lespedeza residues incorporated into the soil have been reported to reduce growth of corn (Zea mays L.) (Langdale and Giddens 1967); rye (Secale cereale L.), ryegrass (Lolium multiflorum Lam.), tall fescue (Festuca arundinacea Schreb.), bermudagrass [Cynodon dactylon (L.) Pers.] and bahiagrass (Paspalum notatum Flugge) (Kalburtji and Mosjidis 1992). There is no information about the interactions of sericea lespedeza with other plants at the root level.

The objectives of this study were: (1) to find if sericea lespedeza root exudates affected seed germination and seedling growth of tall fescue, bermudagrass, and bahiagrass; and (2) to determine if any such response were cultivar dependent.

\section{Materials and Methods}

The effects of sericea lespedeza root exudates on percentage germination and emergence and plant growth of tall fescue, bermudagrass, and bahiagrass were examined in a series of greenhouse experiments. Root exudates obtained from the low-tannin cultivars 'AU Donnelly' and 'AU Lotan' and from the high-tannin cultivar 'Serala' were tested on 3 cultivars of tall fescue ('AU Triumph', endophyte-infected 'Ky-31', and endophyte-free 'KY31 ') and of bermudagrass ('CD-6.69', 'Arizona Common', and 'Guymon'), and 2 of the bahiagrass ('Pensacola' and 'Tifton 9').

Root exudates were obtained by using a modification of the technique described by Papadakis (1977). One hundred seeds of each sericea lespedeza cultivar were planted in separate containers (65-cm long $\times 50-\mathrm{cm}$ wide $\times 35-\mathrm{cm}$ deep) filled with coarse perlite. The bottom and both side panels of the containers were perforated with holes $0.4 \mathrm{~cm}$ in diameter. Each container was placed inside a separate tub $(100-\mathrm{cm}$ long $\times 60-\mathrm{cm}$ wide $\times 51-\mathrm{cm}$ deep $)$ filled to a height of $35 \mathrm{~cm}$ with full strength Hoagland No. 2 nutrient solution (Hoagland and Arnon 1950) which was vigorously aerated. The containers were suspended $17.5 \mathrm{~cm}$ from the bottom of the tubs. Thus, the nutrient solution could wet the perlite, and root exudates from the plants in the containers could diffuse into the nutrient solution in the tub. The space between the container and the tubs was covered with black plastic to reduce water evaporation from the nutrient solution. An additional container filled with perlite but not planted was immersed in a tub with nutrient solution and used as a control. The $\mathrm{pH}$ and electrolytical conductivity were determined for the nutrient solution of each tub in all experiments once a week.

Thirty days after planting the sericea lespedeza cultivars, 2 experiments for each of the 3 grass species were started. In the first experiment, 28 seeds of each cultivar of tall fescue, bermudagrass, and bahiagrass were germinated in coarse perlite (Horticultural Products, W.R. Grace \& Co., Cambridge, Mass.) $)^{1}$ placed in separate boxes $(27$ length $\times 20$ width $\times 6$ depth $\mathrm{cm})$. In the second experiment, 10 seeds of each grass cultivar were planted in 3,399$\mathrm{cm}^{3}$ pots $(17 \mathrm{~cm}$ in diameter) filled with potting soil [ $13 \%$ peatmoss,

'Names of products are included for the benefit of the reader and do not imply endorsement or preferential treatment by the Alabama Agricultural Experiment Station, Auburn University.
$57 \%$ Bassfield loamy fine sand soil (coarse-loamy, siliceous, thermic, Typic Hapludults), and $30 \%$ sand]. This potting soil ( $\mathrm{pH}=5.6$ ) contained $1.9 \%$ organic matter, $1.4 \mathrm{~g}_{\text {total }} \mathrm{N} \mathrm{kg}^{-1}$, and $72 \mathrm{~g} \mathrm{P} \mathrm{kg}^{-1}$. Exchangeable cations were $3.8,1.2$, and $0.4 \mathrm{cmol} \mathrm{kg}^{-1}$ of $\mathrm{Ca}^{2+}$, $\mathrm{Mg}^{2+}$, and $\mathrm{K}^{+1}$, respectively. The plants in the pots were thinned to 5 per pot 20 days after emergence.

Treatments were imposed by watering the plants with nutrient solution taken from the tubs where each of the 3 sericea lespedeza cultivars were growing, as well as nutrient solution from the control (no plants). Each container or pot was watered with $100 \mathrm{ml}$ of the nutrient solutions whenever needed to maintain adequate soil moisture. The pots were leached with tap water every 15 days to avoid salt accumulation in the soil.

Percentage germination and radicle and coleoptile length were measured 7 days after planting in perlite. In soil, the plants were allowed to grow for $\mathbf{5 0}$ days. At the end of this period, shoots were cut at soil level, oven dried at $65^{\circ} \mathrm{C}$ for 72 hours and weighed.

Within each species, data were analyzed as a factorial experiment in a split plot design where cultivars were the main plots and treatments (sericea lespedeza root exudates) were the subplots. There were 6 replications with 1 container or pot per treatment per replication. Comparison between treatment means were done according to the least significant test (Gomez and Gomez 1984).

\section{Results and Discussion}

Germination of tall fescue and bahiagrass grown in perlite was not affected by root excudates (Table 1). Germination of bermudagrass was reduced from 7 to $12 \%$ by root exudates compared to

Table 1. Effect of sericea lespedeza root exudates on percentage seed germination of tall fescue, bermudagrass, and bahiagrass grown in perlite, averaged over cultivars.

\begin{tabular}{lccc}
\hline Exudate source & Tall fescue & Bermudagrass & Bahiagrass \\
\hline & 76 & 93 & $-1 \%$ \\
Control & 72 & 86 & 82 \\
Serala & 71 & 85 & 80 \\
AU Lotan & 71 & 82 & 79 \\
AU Donnelly & ns & 5 & ns \\
LSD $(0.05)$ & & & \\
\hline
\end{tabular}

the control (Table 1). The latter results agree with the reduced germination measured in beet (Beta vulgaris L.) and okra ( $A$ belmoschus esculentus L.) when exposed to root exudates from several crops and weeds (Pope et al. 1985a).

Radicle length of bermudagrass and bahiagrass was reduced by root exudates from sericea lespedeza (Table 2). Similar effects of crop root exudates on the radicle elongation of other plants have been reported by Pope et al. (1985a) and Kalburtzi et al. (1989). The cultivar-treatment interaction was significant $(P=0.01)$ for

Table 2. Effect of sericea lespedeza root exudates on radicle length of tall fescue cultivars and bermudagrass and bahiagrass, averaged across cultivars.

\begin{tabular}{|c|c|c|c|c|c|}
\hline \multirow[b]{2}{*}{ Exudate source } & \multicolumn{3}{|c|}{ Tall Fescue } & \multirow[b]{2}{*}{$\begin{array}{c}\text { Bermuda- } \\
\text { grass }\end{array}$} & \multirow[b]{2}{*}{$\begin{array}{c}\text { Bahia- } \\
\text { grass }\end{array}$} \\
\hline & $\underset{\text { Triumph }}{\text { AU }}$ & $\begin{array}{c}\text { KY-31 } \\
\text { endophyte } \\
\text { infected }\end{array}$ & $\begin{array}{c}\text { KY-31 } \\
\text { endophyte } \\
\text { free }\end{array}$ & & \\
\hline & \multicolumn{5}{|c|}{$\ldots \ldots \ldots-\ldots(\mathrm{cm})-\ldots \ldots \ldots$} \\
\hline Control & 2.9 & 3.1 & 2.8 & 5.5 & 2.8 \\
\hline Serala & 2.9 & 2.5 & 1.9 & 3.6 & 2.1 \\
\hline AU Lotan & 2.5 & 2.4 & 2.3 & 3.6 & 2.0 \\
\hline AU Donnelly & 2.7 & 2.7 & 2.1 & 3.6 & 2.1 \\
\hline $\operatorname{LSD}(0.05)$ & ns & 0.3 & 0.3 & 0.3 & 0.2 \\
\hline
\end{tabular}


radicle length of tall fescue. AU Triumph was not affected by the root exudates whereas both KY-31 had a shorter radicle. Radicle length of endophyte-infected KY-31 was equally reduced by all the root exudates, whereas endophyte-free KY-31 was reduced more by exudates from Serala than from the other sericea lespedeza cultivars. Radicle length was reduced $35 \%$ in bermudagrass and $25-28 \%$ in bahiagrass (Table 2 ).

Coleoptile length of all grass species was reduced by root exudates of sericea lespedeza (Table 3). Wheat and favabean root

Table 3. Effect of sericea lespedeza root exudates on coleoptile length of tall fescue, averaged across cultivars, bermudagrass, and bahiagrass cultivars.

\begin{tabular}{|c|c|c|c|c|c|c|}
\hline \multirow[b]{2}{*}{$\begin{array}{l}\text { Exudate } \\
\text { source }\end{array}$} & \multirow[b]{2}{*}{$\begin{array}{c}\text { Tall } \\
\text { fescue }\end{array}$} & \multicolumn{3}{|c|}{ Bermudagrass } & \multicolumn{2}{|c|}{ Bahiagrass } \\
\hline & & CD-6.69 & $\begin{array}{l}\text { Arizona } \\
\text { common }\end{array}$ & Guymon & Pensacola & Tifton 9 \\
\hline Control & 5.0 & 7.4 & 9.3 & 9.0 & 4.5 & 4.9 \\
\hline Serala & 4.6 & 6.4 & 7.3 & 7.1 & 3.6 & 3.8 \\
\hline AU Lotan & 4.8 & 6.5 & 7.9 & 6.6 & 3.5 & 3.9 \\
\hline $\begin{array}{l}\text { AU Don- } \\
\text { nelly }\end{array}$ & 4.6 & 6.8 & 7.8 & 6.2 & 3.5 & 4.5 \\
\hline $\begin{array}{l}\text { LSD } \\
(0.05)\end{array}$ & 0.3 & 0.6 & 0.8 & 0.6 & 0.5 & 0.2 \\
\hline
\end{tabular}

exudates had similar effects on the growth of each other (Kalburtzi et al. 1989). Coleoptile length of tall fescue was reduced $8 \%$. Cultivar-treatment interaction was significant $(P<0.01)$ for coleoptile length of bermudagrass. Coleoptile length of CD-6.69 was reduced by exudates of Serala and $\mathrm{AU}$ Lotan, but it was not affected by exudates of AU Donnelly. Coleoptile length of Arizona Common was equally affected by the root exudates of the sericea lespedeza cultivars whereas that of Guymon was more affected by AU Lotan and AU Donnelly than by Serala (Table 3).

Cultivar-treatment interaction was significant $(P=0.03)$ for coleoptile length of bahiagrass. Coleoptile length of Pensacola was equally affected by all the root exudates whereas that of Tifton 9 was reduced more by exudates from Serala and AU Lotan than from AU Donnelly (Table 3).

The experiments conducted with soil indicated that percentage of emergence of tall fescue, bermudagrass, and bahiagrass were reduced $5.4,2.0$, and $4.3 \%$ by the root exudates, respectively; however, these reductions were not significant $(P>0.05)$. These results correspond with our previous experiment on the effect of root exudates on percentage of germination of tall fescue and bahiagrass in perlite, but differ from those on bermudagrass (Table 1).

Aboveground biomass of tall fescue and bahiagrass was reduced by root exudates, whereas biomass of bermudagrass was not affected (Table 4). Similar effects of crop root exudates on biomass of other plants have been reported by Pope et al. (1985b) and Kalburtzi et al. (1989).

Cultivar-treatment interaction was significant $(P=0.04)$ for aboveground biomass of tall fescue. AU Triumph was not affected by any of the root exudates. Aboveground biomass of KY-31 endophyte-infected was reduced between 11 and $16 \%$ by all root exudates and aboveground biomass of KY-31 endophyte-free was reduced (19-22\%) by root exudates of AU Lotan and AU Donnelly, but was not affected by Serala root exudates (Table 4).

Bahiagrass cultivars also responded differently to sericea lespedeza root exudates. Aboveground biomass of Pensacola plants was reduced by all root exudates, however, exudates from AU Donnelly decreased biomass of Pensacola plants $40 \%$ whereas Serala and AU Lotan reduced its biomass 13-17\%. Plants of Tifton $9 \mathrm{had}$ 21 to $23 \%$ less biomass when exposed to root exudates from $\mathrm{AU}$ Lotan and AU Donnelly, but were not affected by Serala (Table 4).
Table 4. Effect of sericea lespedeza root exudates on above-ground biomass of tall fescue, bermudagrass averaged across cultivars, and bahiagrass.

\begin{tabular}{|c|c|c|c|c|c|c|}
\hline \multirow{3}{*}{$\begin{array}{l}\text { Exudate } \\
\text { source }\end{array}$} & \multicolumn{3}{|c|}{ Tall fescue } & \multirow{3}{*}{$\begin{array}{c}\text { Bermuda- } \\
\text { grass }\end{array}$} & \multirow{2}{*}{\multicolumn{2}{|c|}{ Bahiagrass }} \\
\hline & \multirow{2}{*}{$\stackrel{\text { AU }}{\text { Triumph }}$} & \multirow{2}{*}{$\begin{array}{l}\text { KY-31 } \\
\text { endo- } \\
\text { phyte } \\
\text { infected }\end{array}$} & \multirow{2}{*}{$\begin{array}{c}\text { KY-31 } \\
\text { endo- } \\
\text { phyte } \\
\text { free }\end{array}$} & & & \\
\hline & & & & & $\overline{\text { Pensacola }}$ & Tifton 9 \\
\hline & $\ldots \ldots$ & $\ldots$ & $-(g$ & $\left.o t^{-1}\right) \ldots$ & $\ldots \ldots$ & $-\ldots$ \\
\hline Control & 4.1 & 3.8 & 3.2 & 10.8 & 5.2 & 5.3 \\
\hline Serala & 3.9 & 3.4 & 3.2 & 10.3 & 4.5 & 5.2 \\
\hline AU Lotan & 4.1 & 3.2 & 2.6 & 10.8 & 4.3 & 4.2 \\
\hline $\begin{array}{l}\text { AU Don- } \\
\text { nelly }\end{array}$ & 3.6 & 3.4 & 2.5 & 10.7 & 3.1 & 4.1 \\
\hline LSD & & & & & & \\
\hline$(0.05)$ & ns & 0.4 & 0.3 & ns & 0.6 & 0.6 \\
\hline
\end{tabular}

The overall response of tall fescue and bahiagrass aboveground biomass is similar to the response of their radicle and coleoptile length, respectively, whereas the response of bermudagrass radicle and coleoptile length were not representative of the effects of sericea lespedeza root exudates on the biomass of this species.

The $\mathrm{pH}$ of the solution containing sericea lespedeza root exudates ranged from 5.4 to 6.5 for the experiments with tall fescue, from 5.4 to 6.4 for the experiments with bermudagrass, and from 6.0 to 6.8 for the experiments with bahiagrass. Electrolytical conductivity of the solution containing root exudates for the experiments with tall fescue, bermudagrass, and bahiagrass ranged from $0.12,0.10$, and 0.14 to $0.21,0.23$, and $0.26 \mathrm{Sm}^{-1}$, respectively. No relationship was observed between $\mathrm{pH}$ or electrolytical conductivity and seedling emergence or growth response. These findings agree with Tang and Young (1982), who found that $\mathrm{pH}$ and concentration of salts were not causative factors in the observed inhibition of lettuce (Lactuca sativa L.) radicle length by bigalta limpograss [Hemarthia altissima (Poir.) Stapf. and Hubb] root exudates.

\section{Summary}

Root exudates from sericea lespedeza had no effect on germination and emergence of bahiagrass but reduced its radicle and coleoptile length and aboveground biomass. Germination, radicle, and coleoptile length, and emergence of bermudagrass decreased when exposed to the root exudates; however, aboveground biomass was not affected. Tall fescue cultivars differed in their response to the root exudates of sericea lespedeza. Establishment of tall fescue in mixture with sericea lespedeza is not likely to be affected; however, the growth of some cultivars is likely to be decreased. Therefore, bahiagrass and some tall fescue cultivars contribution to total yield will be reduced. Conversely, establishment of bermudagrass is likely to be affected, but, once established, its growth is expected to be similar to when grown alone.

\section{Literature Cited}

D'Arcy Lameta, A., and M. Jay. 1987. Study of soybean and lentil root exudates. III. Influence of soybean isoflavonoids on the growth of rhizobia and rhizospheric microorganisms. Plant and Soil 101:267-272.

Gomez, K.A., and A.A. Gomez. 1984. Statistical procedures for agricultural research. 2nd. Ed. John Wiley and Sons, Inc., N.Y.

Hoagland, D.R., and D.I. Arnon. 1950. The water-culture method for growing plants without soil. Circular 347. The College of Agriculture Univ. California, Berkeley.

Hoveland, C.S., and E.D. Donnelly. 1985. The lespedezas. p. 128-135. In: M.E. Heath et al. (eds.) Forages. The science of grassland agriculture. 4th ed. lowa State Univ. Press, Ames.

Kalburtji, K.L., and J.A. Mosjidis. 1992. Effect of sericea lespedeza residues on warm-season grasses. J. Range Manage. 45:441-444.

Kalburtzi, K.L., P.A. Gerakis, and D. Vokou. 1989. Allelopathy between wheat and fababeans as expressed by inhibitory effects on seed germination and growth. Agr. Med. 119:372-382. 
Langdale, G.W., and J.E. Giddens. 1967. Phytotoxic phenolic compounds in sericea lespedeza residues. Agron. J. 59:581-584.

Papadakis, J. 1977. The mechanism of plant competition. Papadakis, J. (ed.), Buenos Aires, Argentina.

Pope, D.F., A.C. Thompson, and A.W. Cole. 1985a. Phytotoxicity of root exudates and leaf extracts of nine plant species. p. 219-234. In: A.C. Thompson (ed.), The chemistry of allelopathy. Biochemical interactions among plants. Amer. Chem. Soc., Washington, D.C.

Pope, D.F., A.C. Thompson, and A.W. Cole. 1985b. The effect of root exudates on soybeans. Germination, root growth, nodulation, and drymatter production. p. 235-241. In: A.C. Thompson (ed.), The chemistry of allelopathy. Biochemical interactions among plants. Amer. Chem. Soc., Washington, D.C.
Richardson, A.E., M.A. Djordjevic, B.G. Rolfe, and R.J. Simpson. 1988. Effects of $\mathrm{pH}, \mathrm{Ca}$ and $\mathrm{Al}$ on the exudation from clover seedlings of compounds that induce the expression of nodulation genes in Rhizobium trifolii. Plant and Soil 109:37-47.

Rovira, A.D. 1969. Plant root exudates. Bot. Rev. 35:35-59.

Tang, Chung-Shih, and Chiu-Chung Young. 1982. Collection and identification of allelopathic compounds from the undisturbed root system of bigalta limpograss (Hemarthia altissima). Plant Physiol. 69:155-160. 